\title{
Isolation of an isoflavonoid and a terpenoid from the heartwood of Baphia nitida Lodd. (camwood)
}

\author{
Gloria Ihuoma NDUKWE*, Amarachi OLUAH, and Godswill Kuta FEKARURHOBO
}

Department of Chemistry, Rivers State University, Nkpolu-Oroworukwo, Port Harcourt, Rivers State, Nigeria

\begin{abstract}
Chromatographic separation of methanolic extract of Baphia nitida heartwood gave two crystalline solids characterized as 3,9-dimethoxy-6aR,11aR-dihydro-6H-benzofuro(3,2-C)[1]benzopyran (also known as homopterocarpin) with molecular formula $\mathrm{C}_{17} \mathrm{H}_{16} \mathrm{O}_{4}$ (1.57\% yield) and 2,4-dimethoxybenzaldehyde $\mathrm{C}_{9} \mathrm{H}_{10} \mathrm{O}_{3}(2.27 \%$ yield). Each of the isolated compounds showed a single spot on developed thin layer chromatographic plate under ultraviolet light $(254 \mathrm{~nm})$ and spray reagent (10\% sulfuric acid in methanol solution). Structural elucidation was achieved using Fourier transform infrared (FT-IR) spectroscopy, one and two-dimension nuclear magnetic resonance (NMR) techniques. Distortionless enhancement by polarization transfer-edited-heteronuclear single quantum coherence (DEPTed-HSQC) was also a useful tool that aided the characterization of the two secondary metabolites isolated from Baphia nitida heartwood.
\end{abstract}

Keywords: Baphia nitida, camwood, isolation, chromatography, secondary metabolites, homopterocarpin, isoflavonoid, terpenoid.

\section{Introduction}

The realization that flavonoids have enormous therapeutic potentials has led to increased interest in them [1]. They are known for their vasoprotective, antiinflammatory, anti-allergic, anti-thrombotic properties [2]. Flavonoids and their conjugates constitute a vast group of natural products and this has made them important phytoconstituents.

Baphia nitida, also known as camwood and African sandalwood, is a shrubby leguminous, hard-wooded tree from central West Africa, often planted in the villages as an ornamental or shade plant and as a source of medicines and dye [3]. The wood is commonly used to make a red dye. Locally, it is used as chew stick for the treatment of toothache and fertility related issues in women [4], it is also used to relieve gastro-intestinal complaints [5-7], inflammation, joint pain, and diarrhea $[8,9]$.

Chemical investigation of the leaves of Baphia nitida revealed the presence of baphianoside [3] and isoflavonoids known as medicarpin and sativan, 6,3,7trihydroxy-2,4-dimethoxyisoflav-3-one $\quad[4, \quad 10]$. Successful isolations of $16-\beta-(\beta-D-$ glucopyranosyl)lanost-1,5,11,15-tetraene-3-yl-6-O(3,4,5-trimethoxycyclohexanoyl)- $\beta$-D-glucopyranoside [11] as well as iminosugars namely: 1-deoxynojirimycin (DNJ); 3-O- $\beta$-D-glucopyranosyl-(DNJ); 6- $O-\beta-\mathrm{D}-$ glucopyranosyl-(DNJ); 1-deoxymannojirimycin (DMJ), 1-deoxyallonojirimycin, 3-epi-fagomine, $2 R, 5 R$ dihydroxymethyl-3R,4R-dihydroxypyrrolidine

(DMDP), $1-O-\beta-\mathrm{D}-$ fructofuranoside of DMDP, 3-O- $\beta$ D-glucopyranosyl-DMDP, and 1,4-dideoxy-1,4-iminoD-arabinitol [12] from $B$. nitida leaves have been reported.
In this paper we report the isolation of an isoflavonoid (homopterocarpin) and a terpenoid (2,4dimethoxybenzaldehyde) from methanolic extract of Baphia nitida heartwood.

\section{Experimental}

\subsection{Materials}

All solvents were redistilled before use. Analytical thin layer chromatography (TLC) was carried out on silica gel $\left(\right.$ Merck $\left.\mathrm{F}_{254}\right)$ precoated aluminum plates. Merck TLC grade silica gel and Merck silica gel (70-230 mesh) were used for vacuum liquid chromatography (VLC) and column chromatography respectively.

\subsection{Instrumentation}

Spots on TLC were detected under UV light $(\lambda=254$ $\mathrm{nm}$ ) while further detections were made by using spray reagent, $10 \%$ sulfuric acid in methanol solution $\left(\mathrm{H}_{2} \mathrm{SO}_{4}-\right.$ $\mathrm{MeOH})$ followed by heating. Melting points were recorded on a Stuart melting point apparatus SMP11 and were uncorrected. FT-IR spectra were recorded on Agilent Cary 630 FT-IR spectrometer. ${ }^{1} \mathrm{H}$ and ${ }^{13} \mathrm{C}$ NMR spectra were taken on Bruker advance III HD (NanoBay) and a BBO probe, operating at $400 \mathrm{MHz}$. All samples were run in $\mathrm{CDCl}_{3}$ and chemical shifts expressed in ppm.

\subsection{Preparation of plant extract}

Dry Baphia nitida heartwood (camwood) was bought from Okwagbe market in Ughelli South Local Government Area, Delta State, Nigeria. The heartwood was chopped into small pieces and milled into a fine powder using Tribest personal blender at room temperature.

\footnotetext{
* Corresponding author. E-mail address: gloria.ndukwe@ust.edu.ng (Gloria Ihuoma Ndukwe)
} 


\subsection{Extraction}

Extraction of the constituents of Baphia nitida heartwood was done by macerating the pulverized plant material (443 g) in $3 \mathrm{~L}$ of methanol for 48 hours [13]. The extract was concentrated using a rotary evaporator (Labrota 4002 ) at $35^{\circ} \mathrm{C}$ to afford a solid red-brown residue in $32.2 \%$ yield.

\subsection{Vacuum liquid chromatography}

Silica gel ( $30 \mathrm{~g})$ was added to $30 \mathrm{~g}$ of the extract residue as material adsorbent for the column and mixed thoroughly. $130 \mathrm{~g}$ of silica gel (TLC grade) was poured into sintered glass funnel and was distributed evenly to a height of $4.5 \mathrm{~cm}$. The material adsorbent was evenly distributed on top of the already loaded silica gel in the sintered glass funnel within a height of $1.5 \mathrm{~cm}$. Gradient elutions were carried out using binary mixtures of $n$ hexane ( $n$-Hex), dichloromethane (DCM) and methanol $(\mathrm{MeOH})$. A total of 208 fractions of $50 \mathrm{ml}$ each were collected and combined based on TLC to afford 10 major fractions (F1 - F10). Fractions were allowed to dry at room temperature, weighed and stored in glass vials for further analysis.

\subsection{Purification of fractions}

VLC fractions F1 and F2 after drying gave ivory coloured crystals $(1.2 \mathrm{~g})$ and coral coloured crystalline lumps $(1.4 \mathrm{~g})$ respectively. F1 and F2 were further subjected to column chromatography [13] using $50 \mathrm{~g}$ of silica gel (70-230 mesh) in a $70 \mathrm{~cm} \times 5 \mathrm{~cm}$ column. The columns were gradient eluted with mixtures of $n$-hexane and dichloromethane in increasing polarities. Fractions collected were monitored using TLC and detection was achieved with UV light and $\mathrm{MeOH}-\mathrm{H}_{2} \mathrm{SO}_{4}$ spray reagent followed by heating.

F1 gave a total of 106 fractions of $5 \mathrm{ml}$ each. Fractions 31-45 (n-Hex-DCM, 9:1) were combined based on TLC and solvent evaporated to afford $\mathrm{F} 1^{1}(0.47$ g, $1.57 \%$ yield).

$\mathrm{F}^{1}{ }^{1}$ was a colourless needlelike crystalline compound which showed as one purple spot on TLC ( $n$ hex-DCM, 1:1) under UV light and when sprayed with $\mathrm{MeOH}-\mathrm{H}_{2} \mathrm{SO}_{4}$ and subsequent heating gave a yelloworange spot with $\mathrm{R}_{\mathrm{f}}$ value of 0.6 .

Crystals from F2 (1.4 g) were similarly further purified [13] to give $\mathrm{F}^{1}{ }^{1}$ (0.68 g, $2.27 \%$ yield) as colourless hair-like crystals which showed as one purple spot on TLC ( $n$-Hex-DCM, 1:1) under UV light and when sprayed with $\mathrm{MeOH}-\mathrm{H}_{2} \mathrm{SO}_{4}$ plus heating, with $\mathrm{R}_{\mathrm{f}}$ value of 0.38 .

\subsection{Libermann-Buchard test}

$\mathrm{F} 1^{1}(10 \mathrm{mg})$ and $\mathrm{F} 2^{1}(10 \mathrm{mg})$ were separately dissolved in DCM. Fresh Liebermann reagent was prepared by adding conc. $\mathrm{H}_{2} \mathrm{SO}_{4}(1 \mathrm{ml})$ to iced acetic anhydride (1 $\mathrm{ml})$. The reagent was poured down the wall of the test tubes containing the dissolved isolates. There was no visible reaction nor colour change for $\mathrm{F} 1^{1}$ but a purpleviolet coloration was observed for $F 2^{1}$ [14].

\section{Results and discussion}

\subsection{Compound $\mathrm{FI}^{1}$}

The isolated compounds were characterized as follows:
Compound F1': colourless needles, $\mathrm{R}_{\mathrm{f}} 0.6, \mathrm{Mp} 60{ }^{\circ} \mathrm{C}$; IR $\gamma_{\max } \mathrm{cm}^{-1} ; 3507,1617,1457,1203$ and 1032. ${ }^{1} \mathrm{H}$ $\operatorname{NMR}\left(\mathrm{CDCl}_{3}\right) \delta: 7.46(\mathrm{~d}, \mathrm{~J}=8.5 \mathrm{~Hz}, \mathrm{H}-1), 7.16(\mathrm{~J}=8.8$ $\mathrm{Hz}, \mathrm{H}-7), 6.68$ (H1, dd, J = 8.5 Hz, 2.5, H-2), $6.50 \delta(\mathrm{J}$ $=2.5, \mathrm{H}-4), 6.47$ (H-8), 6.49 (m, H-10), 5.54 (d, J = 6.7

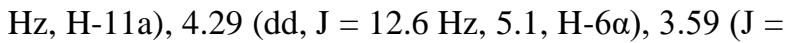
$4.4 \mathrm{~Hz}, \mathrm{H}-6 \beta), 3.55$ (H-6a), 3.63 (H-12) and $3.66(\mathrm{H}-$ 13) ppm. ${ }^{13} \mathrm{C} \mathrm{NMR}\left(\mathrm{CDCl}_{3}\right) \delta: 161.15,161.05,160.73$, 156.63, 131.84, 124.73, 119.14, 112.36, 109.17, 106.37, 101.64, 96.92, 78.59, 66.60, 55.51, 55.38 and $39.8 \mathrm{ppm}$. ASAP-MS (probe) m/z: $285(25)[\mathrm{M}+\mathrm{H}]^{+}\left(\mathrm{C}_{17} \mathrm{H}_{16} \mathrm{O}_{4}\right.$ Measured 285.1128, calculated 285.1127), 257 (8), 177 (7), 161 (48) and $137(100) . F 1^{1}$ showed one spot $\left(\mathrm{R}_{\mathrm{f}} 0.6\right)$ on TLC using $n$-hex-DCM (1:1) as mobile phase. The spot under UV light $(254 \mathrm{~nm})$ was purple and when spray reagent $\left(\mathrm{H}_{2} \mathrm{SO}_{4}-\mathrm{MeOH}\right)$ plus heating was applied, a yellow-orange spot was observed similar to the observations of Keskar et al. [1].

Significant absorptions from the IR spectrum were considered to be a methyl C-H stretch $\left(2933 \mathrm{~cm}^{-1}\right)$, aromatic group $\left(1610 \mathrm{~cm}^{-1}\right.$ and $\left.1505 \mathrm{~cm}^{-1}\right)$ and $\mathrm{C}-\mathrm{O}-\mathrm{C}$ stretch at $1032 \mathrm{~cm}^{-1}$. Yoshikawa et al. reported similar spectrum [15]. Splitting pattern of ${ }^{1} \mathrm{H}$ NMR $5.54 \delta(\mathrm{d}, \mathrm{J}$ $=6.7, \mathrm{H}-11 \mathrm{a}), 4.29 \delta(\mathrm{J}=12.6,5.1, \mathrm{H}-6 \alpha), 3.59 \delta(\mathrm{J}=$ $4.4, \mathrm{H}-6 \beta)$, and $3.55 \delta$ (H-6a) can be related to protons of heterocyclic ring. The spectrum also showed signals characteristic of aromatic protons at $7.46 \delta(\mathrm{d}, \mathrm{J}=8.5$, $\mathrm{H}-1), 7.16 \delta(\mathrm{J}=8.8, \mathrm{H}-7), 6.68 \delta(\mathrm{H} 1, \mathrm{dd}, \mathrm{J}=8.5,2.5$, $\mathrm{H}-2)$ and $6.50 \delta(\mathrm{J}=2.5, \mathrm{H}-4)$.

${ }^{13} \mathrm{C}$ NMR spectrum showed 17 signals indicating the presence of 17 carbon atoms. This agrees with data on the spectral database for organic compounds (SDBS) no. 9311 [9, 10, 16]. In addition, presence of methoxy groups was also consistent with the pterocarpan skeleton. All these were supported by the DEPT-edHSQC (Figure 1) which revealed the presence of methine $(\mathrm{CH})$ and methylene $\left(\mathrm{CH}_{2}\right)$ protons (blue circles) and methyl $\left(\mathrm{CH}_{3}\right)$ protons (green circles).

It is known that all natural pterocarpans exhibit positive and negative cotton effects giving rise to $6 \mathrm{aR} \&$ $11 \mathrm{aR}$ and $6 \mathrm{aS} \& 11 \mathrm{aS}$ configurations respectively [16]. The configuration of compound 1 is $6 \mathrm{aR} 11 \mathrm{aR}$. ASAPMass Spectroscopy showed fragment peaks and structures of characteristic fragment ions on the MS spectrum of $F 1^{1}$ are given (Scheme 1); base peak at $\mathrm{m} / \mathrm{z}$ 137 is due to the loss of a benzofuran derivative. Another peak which is peculiar to pterocarpans is the benzopyrilium ion at $\mathrm{m} / \mathrm{z} 161$. Compound 1 was identified as 3,9-dimethoxy-6aR,11aR-dihydro-6Hbenzofuro(3,2-C)[1]benzopyran (1).

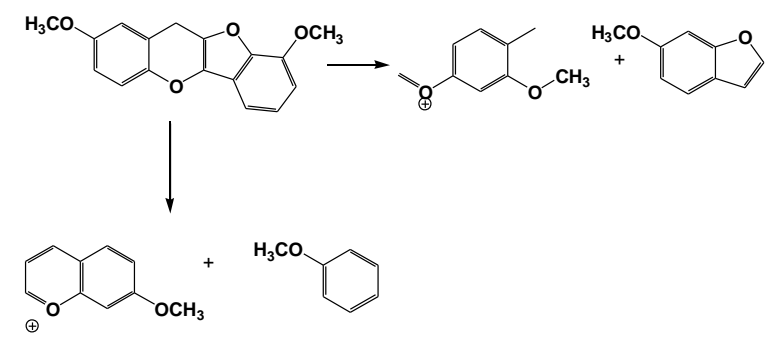

Scheme 1. Fragmentation pattern of compound $\mathrm{F} 1^{1}$ 


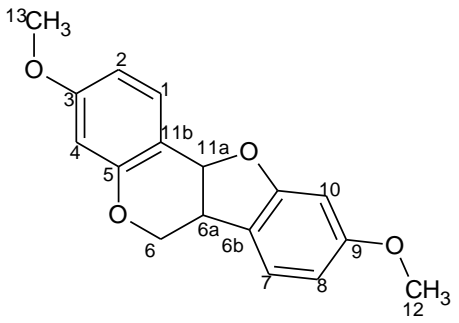

1

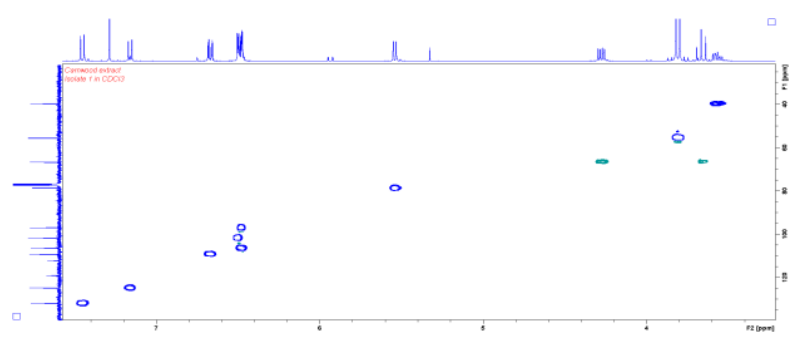

Figure 1. DEPT-ed-HSQC spectrum of compound $\mathrm{F} 1^{1}$

\subsection{Compound $\mathrm{F2}^{1}$}

Compound F2 ${ }^{1}$ : colourless hair-like crystals, $\mathrm{R}_{\mathrm{f}} 0.4, \mathrm{Mp}$ $65^{\circ} \mathrm{C}$; IR $\gamma_{\max } \mathrm{cm}^{-1}$; 3507, 1617, 1457, 1203 and 1032. ${ }^{1} \mathrm{H} \mathrm{NMR}\left(\mathrm{CDCl}_{3}\right) \delta: 10.32(\mathrm{~d}, \mathrm{H}-7), 7.85(\mathrm{~d}, \mathrm{~J}=8.6 \mathrm{~Hz}$, H-6), 6.59 (dd, J = 2.1 Hz, 8.6, H-5), 6.47 ( $\mathrm{J}=2.2 \mathrm{~Hz}$, $\mathrm{H}-3), 3.93(\mathrm{H}-8)$ and $3.90(\mathrm{H}-9)$ ppm. ${ }^{13} \mathrm{C} \mathrm{NMR}$ $\left(\mathrm{CDCl}_{3}\right) \delta$ : 188.37, 166.18, 130.80, 119.09, 105.72, 97.97, 55.64 and $55.62 \mathrm{ppm}$. ASAP-MS (probe) $\mathrm{m} / \mathrm{z}$ : 167 (70) $[\mathrm{M}+\mathrm{H}]^{+}\left(\mathrm{C}_{9} \mathrm{H}_{10} \mathrm{O}_{3}\right.$ measured 167.0708, calculated 167.0708), 167(15), 137(100).

Compound $\mathrm{F}^{1}{ }^{1}(0.68 \mathrm{~g}, 2.3 \%$ yield) showed one spot on TLC ( $R_{f}$ 0.4). The spot under UV light $(254 \mathrm{~mm})$ was purple and on further visualization with spray reagent gave a purple-blue coloration characteristic of terpenoids. Similar observation was reported on the TLC studies of some medicinal plants [17, 18]. IR signals at 2952,1617, 1464, 1278 and $1871 \mathrm{~cm}^{-1}$ were attributed to methyl $\mathrm{C}-\mathrm{H}$ stretch, aromatic group, $\mathrm{O}-\mathrm{CH}_{3}$ and $\mathrm{C}=\mathrm{O}$ stretch respectively. Yoshikawa et al. and Romain et al. [15, 19] also reported similar peaks.

Splitting pattern of ${ }^{1} \mathrm{H}$ NMR at $6.47 \delta(\mathrm{J}=2.2, \mathrm{H}-3)$, $6.59 \delta(\mathrm{dd}, \mathrm{J}=2.1,8.6, \mathrm{H}-5)$ and $7.85 \delta(\mathrm{d}, \mathrm{J}=8.6, \mathrm{H}-6)$ can be related to protons of aromatic ring. This is also similar to the report and in agreement with data on the spectral database for organic compounds (SDBS) no. 9212. DEPT-ed-HSQC (Figure 2) aided the proton to carbon assignments, and it revealed the presence of methine and methyl groups. The assignments are supported by previous literature on similar compound $[19,20]$. Mass spectroscopy showed a base peak fragment at $\mathrm{m} / \mathrm{z} 137$ indicating the loss of a methanal fragment (Scheme 2). Compound F ${ }^{1}$ was confirmed as 2,4-dimethoxybenzaldehyde (2).
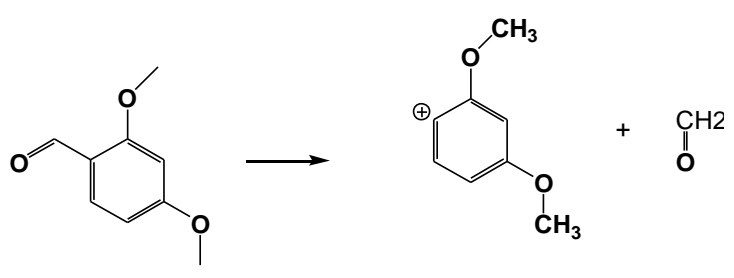

Scheme 2. Fragmentation pattern of compound F2 ${ }^{1}$<smiles>COc1ccc(C=O)c(OC)c1</smiles>

2

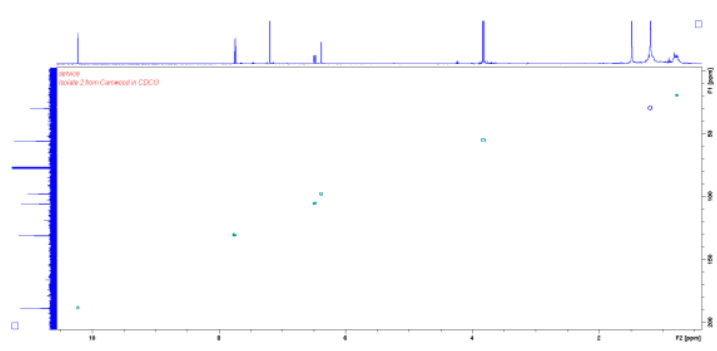

Figure 2. DEPT-ed-HSQC spectrum of compound F2 ${ }^{1}$

\section{Conclusion}

Successful isolation of 3,9-dimethoxy-6aR,11aRdihydro-6H-benzofuro(3,2-C)[1]benzopyran (also known as homopterocarpin) and 2,4dimethoxybenzaldehyde from Baphia nitida Lodd. heartwood was accomplished using chromatographic methods. The two compounds had substantial yields of $1.57 \%$ and $2.27 \%$ respectively. Structural elucidation was done using spectroscopic analyses and values obtained were found to be in agreement with previous publications.

\section{Acknowledgement}

The authors sincerely appreciate the assistance of Vanessa Timmermann and Prof. Cullis M. Paul, Head, Department of Chemistry Leicester University, United Kingdom for their kind assistance with the spectral analyses.

\section{Conflict of interest}

Authors declare no conflict of interest.

\section{References}

[1]. S. Keskar, A. Bhandage, S. Deshmukh, M. Abtryankar, Flavonoids: An overview, Journal of Pharmacy Research 2 (2009) 1148-1154.

[2]. A. Kar, Pharmacognosy and pharmacobiotechnology (Revised expanded second edition), New Delhi: New Age International Limited Publishers (2007).

[3]. B.C. Onyekwere, O.E. JohnBull, R.I. Uchegbu, Isolation and characterization of baphianoside from the leaves of Baphia nitida, Journal of Natural Science Research 4 (2014) 2224-3186.

[4]. O.R. Omobuwajo, S.A. Adesanya, G.O. Babalola, Isofavonoids from Pycnantus angolensis and Baphia nitida, Journal of Phytochemistry 31 (1992) 1013-1014.

[5]. N.D. Onwukaeme, T.Y. Lot, A pharmacological evaluation of Baphia nitida Lodd. (Leguminosae) ethanolic extract on rats and mice, Phytotherapy Research 5 (1991) 254-257. 
[6]. N.D. Onwukaeme, T. Y. Lot, The effect of Baphia nitida Lodd. (leguminosae) extract on the gastrointestinal tract of rats and mice, Phytotherapy Research 6 (1992) 129-132.

[7]. D. Kone-Bamba, Y. Pelissier, Z.F. Ozoukou, D. Kouao, Hemostatic activity of 216 plants used in traditional medicine in the Ivory Coast, Plant Medicinal Phytotherapy 21 (1987) 122-130.

[8] O.O. Adeyemi, O.K. Yemitan, A.E. Taiwo, Neurosedative and muscle-relaxant activities of ethyl acetate extract of Baphia nitida, AFZEL Journal of Ethnopharmacology 106 (2006) 312316.

[9]. O.O. Adeyemi, A.J. Akindele, Antidiarrheal activity of the ethyl acetate extract of Baphia nitida, Journal of Ethnopharmacology 116 (2008) 407-412.

[10]. A. Arnone, L. Camarda, L. Merlini, G. Nasini, D.A.-H. Taylor, Isoflavonoid constituents of the West African red wood Baphia nitida, Phytochemistry 20 (1981) 799-801.

[11]. M. Chabbi, P. Chabert, C. Vanthraon-Serecheau, B. Weniger, O. Modibo, H. Corstigens, I. Sente, L. Declerq, A. Lobstein, Acetylated Flavonol Pentaglycosides from Baphia nitida leaves, Phytochemistry Letters 3 (2010) 70-74.

[12]. A. Kato, K. Noriko, M. Saori, M. Yuka, A. Isao, I. Kyoko, A. Naoki, A. Alison, J.N. Robert, Imminosugars from Baphia nitida, Journal of Phytochemistry 69 (2008) 1261-1265.

[13]. G.I. Ndukwe, C.M. Ojinnaka, A.O. Oyedeji, Novel bioactive triterpenoid saponin from the fruits of Napoleonaea imperialis P. Beauv (Lecythidaceae), International Journal of Chemical Studies 4 (2016) 80-87.

[14]. R. Sheel, K. Nisha, J. Kumar, Preliminary phytochemical screening of methanolic extract of Clerodendron infortunatum, IOSR Journal of Applied Chemistry 1 (2014) 10-13.
[15]. M. Yoshikawa, X. Fegming, M. Hisashe, H. Hiroki, N. Seikou, Structure of new flavonoids from Cuban propolis, Journal of Agriculture and Food Chemistry 53 (2009) 9010-9016.

[16]. A.L. Piccineli, C.M. Fernandez, O. Cuesta-Rubio, L. Rastrelli, Isoflavonoids isolated from Cuban propolis, Journal of Agriculture and Food Chemistry 53 (2005) 9010-9016.

[17]. E.Y Ouafae, A.I.T.O. Nabil, I.G. Quaaziz, S.S.K. Amal, K. Saloua, B.M.B. Bahia, E.L.B. Mohammed, Q.I. Ali, B. Rachid, Phytochemical screening and thin layer chromatography of two medicinal plants: Adasonia digitata (Bombacaceae) and Acacia raddiana (fabaceae), Journal of Pharmacognosy and Phytochemistry 6 (2017) 10-15.

[18].C.O. Alebiosu, A.J. Yusuf, Phytochemical screening, thin layer chromatographic studies and UV analysis of extracts of Citrullus lanatus, Journal of Pharmaceutical, Chemical and Biological Sciences 3 (2015) 214-220.

[19]. R. Costil, F. Fernandez-Nieto, R.C. Atkinson, J. Clayden, $\alpha$-Methyl phenylglycines by asymmetric $\alpha$-arylation of alanine and their effect on the conformational preference of helical Aib foldamers, Organic \& Biomolecular Chemistry 16 (2018) 2757-2761.

[20]. A.D. Khalaji, K. Fejfasovaz M. Dusek, Synthesis and characterization of two dimine Schiff bases derived from 2, 4- dinethe-oxygenaldehyde. The crystal structure of N, N-bis (2,4dinethoxybenzylidene), 1,2-diamiind ethane, Acta Chimica Slovenica 57 (2010) 257-261.

Received: 26.10 .2019

Received in revised form: 23.02.2020

Accepted: 23.02.2020 